\title{
The Effectiveness of Written Arabic Method Based on Contextual Learning on Arabic Education Student at The Islamic Institute of Jember
}

\author{
Bambang Irawan \\ IAIN Jember \\ bambangirawan1976@gmail.com
}

\author{
Received: \\ 08-06-2020 \\ Revised: \\ 16-06-2020 \\ Accepted: \\ 30-06-2020
}

Article History:

\section{Keywords:}

written Arabic method, contextual learning

\begin{abstract}
:
Over several years, the researcher noted that the students in the Arabic Education of State Islamic Institute of Jember were bored with teaching and learning writing skills, and the competence of this skill is low. This research aims to: (1) produce a module in Arabic Writing Teaching Based on The Contextual Teaching Learning that called "al-Kitabah al-MuyassarablilMubtadi'in", (2) find out the level of appropriateness of the use of the module to improve students the competence, (3) describe the effect of the module for students motivation. This research used a method named research and development with the Borg and gall's model. The data were collected through observation, interviews, tests, questionnaires, and document studies. The researcher's analysis was done descriptively for qualitative and statistical information for quantitative data. This research resulted in (1) product in a module based on five characteristics: vocabularies writing, illustrated sentences are writing, pattern sentences, expressions writing, Structures, paragraphs writing, and reflection (2) the module is invalid to improve students' writing competence, and (3) the module based on contextual learning can improve student's motivation.
\end{abstract}

\section{Introduction}

As for the aspects of teaching this article, which was done by the researcher at the Islamic State Institute Jember, one of the obstacles to teaching writing skill, including: the lack of simple books to train learners able to write, lack of books for writing skills that provide sufficient opportunity for the student to participate actively and actively in the educational activities and training gradual sufficient. I did not find the appropriate entrance to teach writing. ${ }^{1}$ Based on the above, the researcher urgently needs to design the educational material in writing skills based on the entrance of teaching and contextual learning. ${ }^{2}$ The researcher believes that this research on that subject is necessary to obtain the form of writing material as an effective option model at the Islamic State Institute of Jember Joy East.

\footnotetext{
${ }^{1}$ Zulfiah Sam, "Metode Pembelajaran Bahasa Arab," Studi Arab: Jurnal Pendidikan Babasa Arab 2, no. 1 (2016): 206220.

2 Fatkhur Rahman, "Problematika Penerjemahan Bahasa Arab Ke Dalam Bahasa Indonesia Bagi Siswa Kelas V Di Madrasah Ibtidaiyah Darut Taqwa Sengonagung Purwosari Pasuruan," Studi Arab: Jurnal Pendidikan Bahasa Arab 8, no. 2 (2017).
} 
As well as to support teachers of the Arabic language in the process of teaching and learning. Given the foregoing, the researcher believes that the teaching of writing skills is not appropriately conducted at the institute. There were problems in teaching and using the entrance of teachers and problems increased by the lack of a particular book supporting the improvement of writing. ${ }^{3}$ Teaching writing appropriate to learners' conditions can build the activity and composition of the language environment in the classroom so that education is effective. ${ }^{4}$

The researcher in this research using the developmental methodology and quantitative, qualitative approach. The researcher uses data collection tools by observation, questionnaire, documents, and interview. 1. How to produce the book in the light of the context of teaching and learning context in the students in the Division of Arabic language teaching at the Islamic State Institute Jember? 2. How effective is the use of writing the teaching of writing skills in the light of contextual teaching and learning to promote the competence of students in the Arabic Language Teaching Division at the Islamic State Institute of Jember? 3. How effective is the use of the textbook of the introduction to writing in light of the context of teaching and learning contextual to promote students' motivation in the Division of Teaching Arabic Language, Islamic State Institute Jember?

\section{Theoretical Review}

\section{Components of Learning and Contextual Learning}

Curriculum development is based on philosophical and conceptual foundations to achieve ideal goals from another effort, curriculum development with a greater focus on academic aspects, and mastery of science. ${ }^{5}$ Some curriculum developers also use this experimental approach. The curriculum is more geared towards acquiring the knowledge, skills, abilities, and skills needed by users to prepare and improve courses based on facts on the ground using research and development. So are the educational materials.

To conduct the contextual education process, the Division of the Institute of Washington presented seven components that were conveyed by Zarkasyi from him, and that the teaching is contextual. These seven are: ${ }^{6}$

\section{Constructivism}

Constructors have the idea that knowledge is not acquired suddenly, but rather through processes and stages he must pass by.

\footnotetext{
3 Miftachul Taubah, "Menciptakan Bi'ah 'Arabiyah Di Lingkungan Universitas Yang Multikultural," Studi Arab: Jurnal Pendidikan Bahasa Arab 8, no. 2 (2017), https://www.jurnal.yudharta.ac.id/v2/index.php/studi$\mathrm{arab} /$ article/view/1760.

${ }^{4}$ Haniatin Nabila, "The Influence of Pedagogic Competence and Professional Competence To Performance Of," International Conference on Ethics of Business, Economics, and Social Science (2011): 556-565.

${ }^{5}$ Stanley Moffatt, “Contextualizing Scientific Research Methodologies” 5, no. 6 (2015): 52-57.

${ }^{6}$ Ahmad Zarkasyi, "Policy on Access, Quality and Competitiveness Islamic Education," Education: Jurnal Pendidikan STAIM Nganjuk 2, no. 1 (2017): 64-83.
} 


\section{Inquiry}

Investigation and study activities are students' achievement of knowledge through observation, interrogation, presentation of hypothesis, collection of facts, and conclusion.

\section{Questioning}

Contextual teaching emphasizes interactive question-and-answer dialogue between all elements of the learning environment. The question is fundamental to reach objective research for science, and the question is useful in the search for information and in the confirmation of what has been learned and in the direction of looking at the unknown aspects. The question has a significant role in investigating, investigating, and scrutinizing so that new information is more reliable. The question has essential functions in the scientific council: knowledge of the learner's abilities in the knowledge of the lesson and revitalizing his learning. To encourage him to reach a specific goal, make him focused on achieving the goal, and guide him to research or conclusion. ${ }^{7}$

\section{Learning community}

Cooperation in learning and contextual education includes cooperation between students, students, students, teachers, or students. Contextual teaching gives much attention to making learning a social process. Learning and its outcome have a higher meaning if it is through the interaction of the scientific group. Collective efforts access one information.

\section{Modeling}

A model presentation will give the teacher a model that shows how to do work before students perform their jobs.

6. Reflection

The reflection is in the form of dialogue or question and answer between teachers and students about the problems and difficulties they find and try to analyze it, rebuilding past activities, emotions, suggestions, and hope. Reflection is a response to new realities, activities, and knowledge.

\section{Authentic assessment}

The correct assessment is the collection of data and information that shows students' development and is collected from the activities they did during the learning. The calendar is not for the teacher but can be done by others.

One of the initial evaluation characteristics is that it is during and after education and can be used for formal and total evaluation and that the place of evaluation and measurement are

\footnotetext{
${ }^{7}$ Nur Rokhmarulloh, "Teknik Pembelajaran Maharah Bahasa Arab," STUDI AR AB: Jurnal Pendidikan Bahasa Arab 8 , no. 2 (2017).
} 
skills and achievements, not just facts. The evaluation is continuous, comprehensive, and complete, and can be used for consideration. ${ }^{8}$ Specifications of the educational book: ${ }^{9}$

1. Outer casing: consists of subject, content, and author name. The subject of the book was "soft writing for beginners," written by Bambang Erawan. Writing joy and reflection

2. Inner casing; includes the subject of the book only.

3. Definition of the book; it consists of the book's subject, the name of the author, the name of the references, the name of the organization, the name of the publication, the name of the publication, the title and the copy of the publication.

4. Introduction; it includes thanksgiving to god and prayer to the prophet and thanks to everyone who contributed to the completion of this book

5. Study plan; it includes the identity of the subject, the activities of the introduction (5 minutes), the primary activities (80 minutes), the conclusion (5 minutes) and the division of time, material and study activities

6. Education Guide; is a statement on how to use the book in the process of teaching and learning in writing.

7. Book units; this book consists of eleven units: dating. Housing, day off, daily life, meal, institute, shopping, atmosphere, interests, .travel .at the doctor.

\section{Method}

The development design used by some researchers is for the Borg and Gall as described above, so the researcher explained the following steps in order to be the curriculum or the development of search and collect data planning, product development project (educational book), initial field trials (first observation), review the results of the experimental test (limited trial), field testing (field investigation), complete field test results, field testing field implementation, final product completion, publishing and using learning and contextual educational. ${ }^{10}$

Kovarian analysis aims to identify the difference between groups governed by the factor or factors. This factor is called the covariable. In general, the analysis of the familiar contrast user was variable IncanY not related to metric (interval or ratio). The independent variable was one non-metric (nominal ordinal). The typical contrast analysis is hardly an analysis of contrast, but it distinguishes the contiguous variable. The fact that the typical contrast analysis is paired with

\footnotetext{
8 Ahmad Zarkasyi, "Manajemen Kinerja Dalam Tafsir Al-Qur'an Dan Hadist Pendekatan Filsafat Tematik," qolamuna: Jurnal studi islam, STISMU Lumajang 2, no. 1 (2016).

9 Miftachul Taubah and Universitas Yudharta Pasuruan, “تأليف الكتاب المنهجي المدرسي" Studi Arab: Jurnal Pendidikan Bahasa Arab 9, no. 2 (2018).

10 Anne Campbell, Brian J. Taylor, and Anne McGlade, : “: Introduction to Quantitative Methods,” Research Design in Social Work: Qualitative, Quantitative \& Mixed Methods, no. August (2018): 80-95.
} 
contrast analysis and regression analysis. The non-metric independent variable is called the agent, and the independent variable is called the covariable variable.

In this research, the tribal test is like the $\mathrm{Y}$ variable, which is the result of students produced after the education process. The independent (standard variable) is the dimensional test results to describe the primary competence of students in the education process. The independent (non-metric) variable is the type of separation divided into the experimental chapter, the pilot group, the officer separation, or the control group. ANAKOVA is made of the imposition of natural, linear, and homogeneity. ${ }^{11}$

1. Normality

The distributional natural is the purpose of knowing the sample data taken, whether it is suitable for the distribution of natural distribution. The natural state is important for the inference, which aims to disseminate the results of the sample data analysis.

2. Linieritas

The linear test aims to determine the distribution of the data, whether the meridian causes its distribution.

3. Homogenitas

The decision-taking of this test is known given the distribution of the data plot. If the distribution of data does not meet in one section, then its distribution is heterogeneous.

\section{Result and Discussion}

\section{The effectiveness of the teaching book to promote student achievement}

To find out how useful the textbook is in terms of the "easy writing for beginners", in the light of the introduction of advanced contextual teaching and learning, the researcher analyzed the data by anakova statistic in terms of natural, linear, and homogeneity.

\footnotetext{
11 Jordan Tovera Salvador, "Exploring Quantitative and Qualitative Methodologies: A Guide to Novice Nursing Researchers" 12, no. 18 (2016): 107-122.
} 
66 | Volume 11, Nomor 1, Juni 2020

1. Natural Status Test

One-Sample Kolmogorov-Smirnov Test

\begin{tabular}{|c|c|c|}
\hline & & Posttest \\
\hline$N$ & & 40 \\
\hline \multirow[t]{2}{*}{ Normal Parameters ${ }^{a, b}$} & Mean & 72.33 \\
\hline & Std. Deviation & 13.213 \\
\hline \multirow[t]{3}{*}{ Most Extreme Differences } & Absolute & .125 \\
\hline & Positive & .072 \\
\hline & Negative & -.125 \\
\hline Test Statistic & & .125 \\
\hline Asymp. Sig. (2-tailed) & & $.114^{\mathrm{c}}$ \\
\hline
\end{tabular}

a. Test distribution is Normal.

b. Calculated from data.

c. Lilliefors Significance Correction.

Due to the previous One-Sample Kolmogorov-Smirnov test table, the following data are known. This case indicates that $\mathrm{H} 0$ is acceptable, i.e. the dimensional test data follows the normal distribution.

2. Linear

\section{Levene's Test of Equality of Error Variances a}

Dependent Variable: Posttest

\begin{tabular}{|l|l|l|l|}
\hline $\mathrm{F}$ & df1 & df2 & Sig. \\
\hline 8.544 & 1 & 38 & .006 \\
\hline
\end{tabular}

Tests the null hypothesis that the error variance of the dependent variable is equal across groups.

\section{a. Design: Intercept + Pretest + Perlakuan}

Based on the previous Levene test, the result of the F Levene 8.554 test is known to have a significant result of 0.006 . The result of the task is 0.006 smaller than the important result $(\alpha)=$ 0.05. Therefore, this result indicates that $\mathrm{H} 0$ is a payoff. It is known that the difference in errors between groups is not heterogeneous.

3. Linear

ANOVA Table

\begin{tabular}{|c|c|c|c|c|c|c|c|}
\hline & & & $\begin{array}{l}\text { Sum of } \\
\text { Squares }\end{array}$ & df & Mean Square & $F$ & Sig. \\
\hline \multirow[t]{5}{*}{ Posttest * Pretest } & \multirow[t]{3}{*}{ Between Groups } & (Combined) & 5500.275 & 23 & 239.142 & 2.924 & .015 \\
\hline & & Linearity & 3812.091 & 1 & 3812.091 & 46.613 & .000 \\
\hline & & Deviation from Linearity & 1688.184 & 22 & 76.736 & .938 & .564 \\
\hline & \multicolumn{2}{|l|}{ Within Groups } & 1308.500 & 16 & 81.781 & & \\
\hline & \multicolumn{2}{|l|}{ Total } & 6808.775 & 39 & & & \\
\hline
\end{tabular}

Program Studi Pendidikan Bahasa Arab Universitas Yudharta Pasuruan https://jurnal.yudharta.ac.id/v2/index.php/studi-arab 
The previous table results in the linear test between the before-test variable and the dimensional test change. From the previous table, the result of the $F$ test for deviation from linearity 0.938 is also known as the result of significant denote $0.564=0.05$, so the h0 zero hypotheses are acceptable, meaning there is a relationship between tribal test results and dimension test results. Therefore, these results are appropriate for the assumption of sin.

Measures of Association

\begin{tabular}{|l|r|r|r|r|}
\hline & \multicolumn{1}{|c|}{ R } & R Squared & \multicolumn{1}{c|}{ Eta } & Eta Squared \\
\hline Posttest * Pretest & .748 & .560 & .899 & .808 \\
\hline
\end{tabular}

The result of $\mathrm{R}=0.748(0.60-0.799)$ indicates that there is a strong relationship between tribal and dimensional test results.

4. Anakova Test

\section{Descriptive Statistics}

Dependent Variable: Posttest

\begin{tabular}{|l|r|r|r|}
\hline Perlakuan & \multicolumn{1}{|c|}{ Mean } & Std. Deviation & \multicolumn{1}{c|}{$\mathrm{N}$} \\
\hline Kelas Eksperiman & 72.85 & 13.108 & 20 \\
Kontrol & 71.80 & 13.637 & 20 \\
Total & 72.32 & 13.213 & 40 \\
\hline
\end{tabular}

The previous table explains the descriptive statistic. The variable analyzer is the pre-test variable, which results from the 20 students in the pilot group and the control group - 20 students - before the education process. Based on the table, the results of the average medicine in the experimental group in the tribal test group are 72.85 . The results of the average medicine in the tribal test group are 71.80. Hence you know that the results of the experimental group have a higher average than the control group.

Tests of Between-Subjects Effects

Dependent Variable: Posttest

\begin{tabular}{|l|r|r|r|r|r|}
\hline Source & \multicolumn{1}{|c|}{$\begin{array}{c}\text { Type III Sum } \\
\text { of Squares }\end{array}$} & df & Mean Square & \multicolumn{1}{c|}{ F } & \multicolumn{1}{c|}{ Sig. } \\
\hline Corrected Model & $3963.335^{\mathrm{a}}$ & 2 & 1981.667 & 25.768 & .000 \\
Intercept & 2144.246 & 1 & 2144.246 & 27.882 & .000 \\
Pretest & 3952.310 & 1 & 3952.310 & 51.393 & .000 \\
Perlakuan & 151.244 & 1 & 151.244 & 1.967 & .169 \\
Error & 2845.440 & 37 & 76.904 & & \\
Total & 216045.000 & 40 & & & \\
Corrected Total & 6808.775 & 39 & & & \\
\hline
\end{tabular}

a. R Squared $=.582$ (Adjusted R Squared $=.560$ ) 
Based on the Between-Subjects Effects test table, you know that the F test result between the trial and control groups is 1,967 with Sig, which is 0.169 . Because of the result of Sig $=0.05$, therefore, there is no significant difference in the results of the dimensional test between the experimental group and the control group.

The ANAKOVA $\mathrm{F}$ test indicates that the effect between the experimental and control groups according to the tribal test results is 51.393 with the Sig result, which is 0.00 because of the result of Sig $=0.05$. Therefore, zero $\mathrm{H} 0$ is a return, which means that the dimensional test results are different between the two groups.

From the results of the analysis by SPSS 22, you know that the dependent variable data are taken from the naturally occurring community so that it can be performed using Analisis Kovarian (ANAKOVA). Given the linear test, it is known that the tribal test variable (the ability of students before the dimensional test) meets the linear assumption. While the two groups (control and experiment) cannot be tested for sin due to a small number of two groups $(\mathrm{k}=2)$.

The results of the homogeneity test for the anakova model indicate that the distribution is heterogeneous. This is related to the realization of the assumption related to the anakova model, which aims to know the difference scoring of the dimensional test in the two groups concerning the experimental group.

Based on the F-control test and experimental categories, it can be noted that there are no differences in the values of the two dimensions by taking into account previous student grades. This shows that the experimental layer did not show a higher value than the previous layer; in other words, the experiment's experiment applied to the experimental layer did not have a better effect than the control class. This may be due to the lack of time to apply the textbook "Easy Writing for Beginners".

\section{How useful is the teaching book, easy writing for beginners in the light of the introduction of teaching and contextual learning to promote student motivation}

Due to the results of the surveys' analysis, the effectiveness of the use of the teaching book of the introduction is known to be the writing in the light of the introduction of teaching and contextual learning to promote students' motivation from the following elements.

1. I want to ask about an educational material that I don't always understand.

The answers to this first question indicate that 17 students answered excellently, and 3 students answered well. Hence it is known that $85 \%$ of students ask very much incomprehensible educational materials and $15 \%$ of students too much. Due to these answers, students were motivated to ask questions high through the educational materials in the developed textbook called "Easy Writing for Beginners".

2. I am happy to write after I used the book "Easy Writing for Beginners"" 
The students' answers to this question consisted of that one student answered excellently, and 13 students answered very well, and 6 students answered well. Hence he knows that 5\% of students are happy to write after they used the book "Easy Writing for Beginners" in a very high degree and $65 \%$ of them are happy to write after they used the book "Easy Writing for Beginners" in a high score and 3\% of them are happy to write after they used The book "Easy Writing for Beginners" in a medium degree. Due to these answers, the students were motivated to write at the "high"".

3. The Book "Easy Writing for Beginners " has wonderful opinions.

The students' answers to this question consisted of that two students answered excellently 6 students answered very well, and 5 students answered well. It is here that the developer book's ideas or opinions are known to be fantastic $70 \%$ fascinating.

4. I believe in the results of my work psychologically.

The students' answers to this question consisted of that 9 students answered excellently, 13 students answered very well and 6 students answered well. Hence, he knows that $45 \%$ of students believe in the results of my work psychologically. 65\% believe in the results of my work psychologically and 30\% believe in the results of my work psychologically. Due to these answers, the students were motivated by the results of their own work and "high".

5. I encourage you to write after seeing pictures or drawings.

The students' answers to this question consisted of 11 students answering excellently, 6 students answered very well, and 3 students answered well. Hence, it is known that $55 \%$ of students are encouraged to write after seeing pictures or drawings, $65 \%$ of them encourage to write after seeing pictures or drawings, and 30\% encourage to write after $\mathrm{i}$ have seen pictures or drawings. Due to these answers, the students were motivated to write after seeing the pictures or the drawings.

6. I love learning properly in the context of everyday life.

The students' answers to this question consist of edited that 16 students answered excellently and 3 students answered very well and the student answered acceptablely. Hence, $80 \%$ of those who like to learn properly in the context of everyday life, $15 \%$ of them like to learn properly in the context of everyday life, and 5\% like to learn appropriately in the context of everyday life. Given these answers, students were motivated to learn appropriately in the context of everyday life.

7. Spend my free time to train writing by watching the model or examples.

The students' answers to this question consisted of that 3 students answered excellently, and 11 students answered very well, and 5 students answered well and the student answered acceptably. Hence it is known that $15 \%$ of those who love to spend leisure time to train writing 
by watching the model or examples, and $55 \%$ spend free time to train writing by watching the model or examples, and $25 \%$ of them spend their free time to train writing by watching the form or the examples, and $5 \%$ of them spend their free time to train. Write by seeing the form or examples. Due to these answers, students were motivated to spend their free time training writing by watching the form of the examples "elevated".

8. I feel confident if I find out how to write on psychological experiences.

The students' answers to this question consisted of that 12 students answered excellently, and 7 students answered very well, and the student answered acceptably. Hence he knows that $60 \%$ of those who feel confident if they find how to write on psychological experiences and $30 \%$ feel confident if they find how to write on psychological experiences and $10 \%$ feel confident if any how to write on psychological experiences. Due to these answers, students were motivated to spend writing on psychological experiences that were "too high".

9. I like to think of ideas in educational science.

The students' answers to this question consist of edited that 12 students answered excellently, and 8 students answered very well. Hence, he knows that $60 \%$ of those who like to think about ideas in educational science and $40 \%$ of them like to think about ideas in educational science. Given these answers, students were motivated to think about educational science ideas. Due to the answer to the previous questions, we find that the student motivation rises to a high level of $85.7 \%$ at the estimate of "Very good".

\section{Conclusion}

Based on the data obtained by the researcher and analyzed throughout the research process, the results of the research were obtained from the production of the product and data from students, experts, and tribal and dimensional tests. The researcher can summarize these findings as follows: The educational book developed for the skill of writing in the light of teaching and contextual learning has characteristics: in terms of content consists of the outer cover, the inner cover, the identity of the book, the logo, the gift page, the introduction, the contents, the study plan, the teaching manual, the book units, and the list References, vocabulary list, personality of life, and back cover. In terms of appearance, it consists of the outer shell, the inner casing, the contents, and the back cover. The educational book is valid for use and valid as follows: Due to the arbitration of three experts, this book is valid in terms of educational materials $93 \%$. In terms of educational means $81 \%$, and terms of the language used $97 \%$. The researcher decides that the proficiency of students in writing skills has not been effective after the use of this book, and this is because there is not enough time to apply it. That motivating 
students after conducting research with the educational book developed for writing skill is very good that they are all excited with the presentation of topics.

\section{References}

Campbell, Anne, Brian J. Taylor, and Anne McGlade. : “: Introduction to Quantitative Methods.” Research Design in Social Work: Qualitative, Quantitative \& Mixed Methods, no. August (2018): 80-95.

Moffatt, Stanley. "Contextualizing Scientific Research Methodologies” 5, no. 6 (2015): 52-57. Nabila, Haniatin. "The Influence of Pedagogic Competence and Professional Competence To Performance Of." International Conference on Ethics of Business, Economics, and Social Science (2011): 556-565.

Rahman, Fatkhur. "Problematika Penerjemahan Bahasa Arab Ke Dalam Bahasa Indonesia Bagi Siswa Kelas V Di Madrasah Ibtidaiyah Darut Taqwa Sengonagung Purwosari Pasuruan.” Studi Arab: Jurnal Pendidikan Bahasa Arab 8, no. 2 (2017).

Rokhmarulloh, Nur. “Teknik Pembelajaran Maharah Bahasa Arab.” STUDI ARAB: Jurnal Pendidikan Bahasa Arab 8, no. 2 (2017).

Salvador, Jordan Tovera. "Exploring Quantitative and Qualitative Methodologies : A Guide to Novice Nursing Researchers" 12, no. 18 (2016): 107-122.

Sam, Zulfiah. "Metode Pembelajaran Bahasa Arab." Studi Arab: Jurnal Pendidikan Bahasa Arab 2, no. 1 (2016): 206-220.

Taubah, Miftachul. "Menciptakan Bi’ah 'Arabiyah Di Lingkungan Universitas Yang Multikultural." Studi Arab: Jurnal Pendidikan Bahasa Arab 8, no. 2 (2017).

Taubah, Miftachul, and Universitas Yudharta Pasuruan. “تأليف الكتاب المنهجي المدرسي" Studi Arab: Jurnal Pendidikan Bahasa Arab 9, no. 2 (2018).

Zarkasyi, Ahmad. "Manajemen Kinerja Dalam Tafsir Al-Qur'an Dan Hadist Pendekatan Filsafat Tematik." qolamuna : Jurnal studi islam, STISMU Lumajang 2, no. 1 (2016). . "Policy on Access, Quality and Competitiveness Islamic Education." Education: Jurnal Pendidikan STAIM Nganjuk 2, no. 1 (2017): 64-83. 
72 | Volume 11, Nomor 1, Juni 2020 